\title{
Just Disagreement: Indeterminacy and Rationality in the Rule of Law
}

\author{
Christopher L. Kutz
}

"It feels as if I have fallen unexpectedly into a deep whirlpool which tumbles me around so that I can neither stand on the bottom nor swim up to the top." Descartes wrote these words of despair in his Second Meditation as he contemplated the possibility that he might be dreaming-or worse, that an evil demon might be deceiving all his senses. For Descartes, however, skeptical despair was only the starting point of epistemological inquiry. The end point of this inquiry was not skepticism, but a new understanding of certainty and of the possibility of knowledge.

Since Descartes, skeptical considerations have continued to serve as powerful epistemological tools, helping us to investigate and refine our ideas of what it is to know and to believe. As an end station, the radical doubt characteristic of philosophical skepticism is barren, for it fails to make sense of our practices of argument and assertion, belief and doubt. But as an investigatory tool, skepticism is extremely fruitful, for it requires us to clarify and defend-and perhaps deeply transform-our philosophical conception of what it means to justify claims of knowledge and belief. ${ }^{2}$

Recently, legal scholars have adopted certain forms of skepticism, originating largely in philosophical arguments about the nature of language use and argument, which they claim give reason to doubt the viability of a political regime of justly applied laws. Critical Legal Studies (CLS) scholars and sympathizers like Joseph Singer, Mark Kelman, and Anthony D'Amato, and the feminist theorist Ann Scales, have appropriated these philosophical arguments in order to criticize the ideology of "liberal legalism," a conception of political authority whose exercise is mediated by law. ${ }^{3}$ These scholars argue

1. 2 Rene Descartes, Meditations on First Philosophy, in The PhilosophiCAL Writings of DESCARTES 16 (John Cottingham et al. trans., Cambridge Univ. Press 1984) (1642).

2. See generally BARRY STRoud, The SignifiCANCE OF PHILOSOPHICAL SCEPTICISM (1984).

3. Legal skeptics have argued against claims of legal justification or certainty on a variety of linguistic and nonlinguistic grounds. Scholars who rely on Wittgensteinian or deconstructionist doubts about the determinacy of language include: Anthony D'Amato, Aspects of Deconstruction, 85 Nw. U. L. REV. 113 (1990) [hereinafter D'Amato, Deconstruction]; Anthony D'Amato, Pragmatic Indeterminacy, 85 Nw. U. L. REV. 148 (1990) [hereinafter D'Amato, Pragmatic Indeterminacy]; Gary Peller, The Metaphysics of American Law, 73 CAL. L. REv. 1151 (1985); Ann C. Scales, The Emergence of Feminist Jurisprudence: An Essay, 95 YALE L.J. 1373 (1986); Joseph W. Singer, The Player and the Cards: Nihilism and Legal Theory, 94 YALE L.J. 1 (1984); and Mark V. Tushnet, Following the Rules Laid Down: A Critique of 
that the inherent indeterminacy of language and rules justifies doubts about the determinacy of any legal regime and its exercise of authority. To the extent that liberal legalism rests on a foundation of determinate rules and their application, philosophical skepticism rebuts its claims to legitimacy.

In response to this skeptical attack, liberal defenders of a law-based political order have largely divided into two camps. The first is represented by Ronald Dworkin, who argues that a legal system is indeterminate only if moral and political principles and nonsyllogistic forms of argument are not allowed to count as legal argument. When these argumentative sources and techniques are permitted, then the law will provide determinate answers to most, if not all, significant questions. ${ }^{4}$ The second camp consists of self-styled "pragmatic" liberals like Richard Posner, who concede that legal systems may be moderately indeterminate, but who argue that legitimate systems require only provisionally acceptable argument, whose ultimate mark of rightness is neither logical rigor nor transcendent moral truth but consensus by an ideal community of legal deliberators. ${ }^{5}$

This Note argues that scholars on all sides of the debate have failed to capture the interest and importance of skeptical doubt for legal theory. CLS writers, attracted by the power of skeptical arguments, have refused to acknowledge that skeptical doubts are compatible with the possibility of rational argument. Conversely, liberals, both determinate and pragmatic, have failed to take seriously the relevance of pervasive indeterminacy for the crucial notion of legal justification. To be sure, skeptical arguments support the

Interpretivism and Neutral Principles, 96 HARV. L. REV. 781 (1983). Legal skeptics also argue that traditional techniques of legal reasoning are vacuous due to the pervasiveness of conflicting legal norms, to the dependence of legal argument on controversial ways of describing fact situations, and to the malleability of precedential reasoning. Skeptics working in this vein include: David Kairys, Legal Reasoning, in THE Politics of LAW: A PROGRessive CrItIQUe 11 (David Kairys ed., 1982); MARK Kelman, A Guide to Critical Legal Studies (1987) [hereinafter Kelman, Guide to CLS]; Mark Kelman, Interpretive Construction in the Substantive Criminal Law, 33 STAN. L. REV. 591 (1981) [hereinafter Kelman, Interpretive Construction]; Tushnet, supra; and Roberto M. Unger, The Critical Legal Studies Movement, 96 HARV. L. REV. 563 (1983). Not all scholars who employ skeptical arguments end up in a skeptical position. For example, although Scales rejects the ideal of "objectivity," she also argues for more expansive and contextually sensitive forms of legal reasoning. See Scales, supra, at 1387-88.

4. See, e.g., RONALD DWORKIN, LAW's EMPIRE 65-101, 271-75, passim (1986) [hereinafter DWORKIN, LAW's EMPIRE]; RONALD DWORKIN, Hard Cases, in TAKING RIGHTS SERIOUSLY 81 (1977) [hereinafter DWORKIN, Hard Cases]. Ken Kress offers arguments along this line, although his own position also reflects elements of the pragmatist camp discussed infra note 5 and accompanying text. See Ken Kress, Legal Indeterminacy, 77 CAL. L. REV. 283, 320-31 (1989) [hereinafter Kress, Legal Indeterminacy]; see also Ken Kress, A Preface to Epistemological Indeterminacy, 85 Nw. U. L. REV. 134 (1990) [hereinafter Kress, Preface].

5. See, e.g., Richard A. Posner, The Jurisprudence of Skepticism, 86 MICH. L. REV. 827 (1988); ANdrew AltMan, Critical Legal Studies: A Liberal Critique (1990); John Stick, Can Nihilism Be Pragmatic?, 100 HARV. L. REV. 332 (1986). Lawrence Solum concedes that the legal system has areas of moderate indeterminacy - what I am calling "underdeterminacy"- - but argues that such indeterminacy makes little if any "practical difference to the parties to a dispute." Lawrence B. Solum, On the Indeterninacy Crisis: Critiquing Critical Dogma, 54 U. CHI. L. REv. 462, 495 (1987). Robert J. Lipkin's argument that determinate foundations can be replaced by a model of Rawlsian reflective equilibrium is also a version of the pragmatist response. See Robert J. Lipkin, Indeterminacy, Justification and Truth in Constitutional Theory, 60 FORDHAM L. REV. 595 (1992). 
pragmatists' claim that the quest for absolute certainty must be replaced by the more modest goal of provisional justification. ${ }^{6}$ But in retreating from the ideal of transcendent truth or absolute legal justification to an ideal of convergent decisions, pragmatists fail to exploit the powerful potential of recognizing divergence and plurivocity as intrinsic to healthy legal institutions. Skeptics may prod us ultimately to see divergence and conflict not only as ineradicable, but also as values in themselves, necessary to the flourishing of a rational and reflective legal culture.

Part I of this Note begins by discussing the relationship between indeterminacy and legal authority generally; it then proceeds to delineate more precisely the different conceptions of indeterminacy that motivate legal skepticism. Skeptical authors have detected each of these forms of indeterminacy in a variety of legal contexts. Part II examines the claim that law is semantically indeterminate: that the particular words in which laws are written are-like language generally - too vague or unconstraining to provide positive guidance to judges. Part III takes up two non-semantic forms of indeterminacy: the claim that judicial decisions rely crucially on unargued-for characterizations of background facts, such that legal reasoning plays little role in determining outcomes; and the claim that permissible forms of legal reasoning are either too restrictive to provide conclusions, or too flexible to support the conclusions reached. Part IV discusses the issue of normative indeterminacy: the norms and principles embedded in a complex legal system are, by virtue of their content and not merely their language, either too permissive to entail specific judicial conclusions, or too deeply conflicting to resolve legal problems. This Note concludes that the conflict and indeterminacy that is inherent in the law is both ineradicable and deeply valuable to a self-scrutinizing moral and political culture.

\section{WHAT IS INDETERMINACY AND WHY DOES IT MATTER?}

Why should indeterminacy matter to liberalism? Writers who focus on law's indeterminacy target the structural feature of liberalism that houses its more substantive commitments to autonomy and equality: its commitment to the ideal of the rule of law. ${ }^{7}$ In the liberal conception of political institutions, decisions about the exercise of public authority should be made on the basis of publicly available rules and standards that are capable of determining concrete outcomes. The core idea is that in a democratic legal order, these

6. Posner describes his skepticism as "a mood or attitude-a disposition to scoff at pretensions to certainty, to question claims (even my own) to the possession of powerful methodologies founded on professional expertise." Posner, supra note 5, at 829.

7. See, e.g., Duncan Kennedy, Legal Formality, 2 J. LEGAL STUD. 351, 351-54 (1973); Singer, supra note 3, at 12 ("Determinacy is necessary to the ideology of the rule of law, for both theorists and judges. It is the only way judges can appear to apply the law rather than make it."). 
standards must flow from collective decisions made by the citizens of the regime, such that the connection between the exercise of authority and the will of the majority is relatively tight. ${ }^{8}$ The rule of law is a necessary component of any liberal political regime, and an attack on it also targets the coherence of liberalism.

Authors as different as Roberto Unger and Ronald Dworkin share the premise that legitimate government under law is impossible if law is substantially indeterminate. ${ }^{9}$ The possibility of arriving at conflicting conclusions from similar premises is taken to mean that no conclusion can be justified, at least if justification means that the conclusion follows rationally and nontrivially from a well-defined set of premises. If no such conclusions are available, political actors could offer only spurious justifications of any exercise of authority by reference to public rules, and the rule of law would impose upon them no genuine constraint. In general, the legitimacy of a regime comes into question precisely to the extent that the actual exercises of its authority cannot be rationally justified by public rules. ${ }^{10}$

Indeterminacy may pose practical as well as theoretical problems for legitimacy by frustrating 'citizens' ability to predict the legal consequences of their actions. It is often thought unfair to impose legal burdens or penalties on citizens who have not been given a chance to modify their conduct in order to avoid those consequences. ${ }^{11}$ If a liberal regime is committed to protecting the general freedom and autonomy of its citizens, then uncertainty decreases their ability to shape their lives on their own terms. ${ }^{12}$ At the same time, uncertainty about legal consequences increases the risk (and hence cost) of desirable activities. A liberal regime tries to create a sphere in which beneficial transactions freely take place; uncertainty and risk impede the goal of allocative efficiency.

However, uncertainty is not the primary concern of skeptical legal critics. For, these critics argue, legal decisions and outcomes are often highly predictable - but on the basis of external factors like racial and class bias rather

8. See Alexander M. BiCKel, The Least Dangerous Branch 19 (2d ed. 1986) (stating that policymaking power of representative institutions is distinguishing feature of democratic political systems); JOHN H. ELY, DEMOCRACY AND DISTRUST 4-7, $101-04$ (1980) (same); cf. Jerry L. Mashaw, Prodelegation: Why Administrators Should Make Political Decisions, 1 J.L. ECON. \& ORGANIZATION 81, 86-88 (1985) (noting argument that citizens in democracy expect close connection between majoritarian institutions and legal decisions); DwORKIN, Hard Cases, supra note 4, at 84 (same).

9. See Unger, supra note 3, at 564-65, 576-77; DwORKIN, Hard Cases, supra note 4, at 81-86; see also Singer, supra note 3, at 14; Kress, Legal Indeterminacy, supra note 4, at 285.

10. In the case of democratic legal orders, where justification ostensibly rests on collectively authorized norms, legal indeterminacy adds a second insult, for the judge's only claim to exercise political authority is founded on her claim to represent the will of the collective. See ELY, supra note 8, at 4-7.

11. See DAVID LyONS, ETHICS AND the RULE of LAW 201 (1984) ("Considerations of faimess ... argue against penalizing people for doing what they had no reason to believe would be punishable.").

12. See H.L.A. HART, Legal Responsibility and Excuses, in PUNISHMENT AND RESPONSIBILITY 28, $45-$ 50 (1968) (arguing that predictability of legal consequences maximizes autonomy). 
than on the basis of legal doctrine. ${ }^{13}$ Dworkin, by contrast, defends the determinacy of law but argues that if the legal issues at stake are controversial or difficult, the demands of legitimacy are satisfied so long as cases are decided rightly even if unpredictably. ${ }^{14}$ The chief skeptical worry about legal indeterminacy is that the pretense of legality masks the extent to which systematic bias and prejudice affect decisions by public institutions. Citizens are thereby misled about the actual reasons for their oppression and are therefore unable to focus their resistance and resentment upon the real cause of their suffering.

In the context of these debates, indeterminacy has both a local and a systemic sense. The local sense is semantic: a word or sentence is said to be indeterminate if, in some cases, there is no way to say unequivocally whether the term applies or whether the sentence is true. For example, a sentence like "My youth lasted six million minutes" is indeterminate, because we have no way of establishing the exact boundaries of "youth" so as to settle the issue. Such a sentence has no "truth-value"-there is "no fact of the matter," in philosophers' terms, whether it is true or false-even though each word in the sentence has a meaning we can grasp.

Legal theorists are worried not just about the truth-values of particular sentences, but about the capacity of a legal system as a whole to generate justifiable conclusions from a set of authoritative sources providing premises. Thus, legal theorists usually invoke one of two systemic notions of indeterminacy. Sometimes the notion employed is the following:

(1) A system of laws is indeterminate if, in a substantial number of cases, more than one conclusion is justified by the authoritative legal sources.

This sense of indeterminacy may be better thought of as underdeterminacy: the legal system permits the logical derivation of more than one conclusion from any given set of premises. ${ }^{15}$ This type of indeterminacy can therefore vary in degree, depending upon the number of possible conclusions that can be logically derived from the premises. The severity of the consequences for

13. As Brian Leiter notes, predicting legal outcomes on nonlegal grounds was a major focus of the work of Legal Realists like Karl Llewellyn, Jerome Frank, and Underhill Moore. Brian Leiter, Legal Realism and Varieties of Legal Indeterminacy 73-97 (Sept. 27, 1993) (unpublished manuscript, on file with the author); see also Singer, supra note 3, at 19-25 (arguing that legal indeterminacy is separate from problem of "arbitrariness"; indeterminacy and predictability are compatible).

14. RONALD DWORKIN, A Reply to Critics, in TAKING RIGHTS SERIOUSLY, supra note 4, at 291, 338 ("We take a mean view of ourselves if we suppose that this practice [of adjudication] is reliable only to the extent that it provides valuable predictions about how official power will be used.").

15. The distinction drawn here is consistent with that drawn by Solum between underdeterminacy and indeterminacy. Solum, supra note 5 , at 473 . Singer expresses the notion in a psychological rather than a logical form: "The claim that a legal doctrine is indeterminate means that the doctrine allows choice rather than constraining or compelling it." Singer, supra note 3 , at 11. 
legitimacy will depend on the importance of the area in which underdeterminacy is claimed. Even if a legal system has pockets of "easy cases," areas where only one conclusion is logically justified, worries may be raised if central and pervasive areas of dispute, such as voting rights or contractual liability, often give rise to varying conclusions. ${ }^{16}$ Thus, a skeptic need only claim that there are important areas of the law in which legal rules do not logically entail one and only one conclusion. ${ }^{17}$

Significantly, underdeterminacy is not a justificatory notion. The logical possibility of drawing multiple conclusions from a set of legal premises need not mean that the conclusions derivable from the legal sources are rationally unsupported by those sources. ${ }^{18}$ Rather, the lack of any justificatory relation between legal premises and legal conclusions represents a stronger type of systemic or rational indeterminacy:

(2) A system of laws is (rationally) indeterminate if there is no appropriate justificatory relationship between conclusions of the system and normative premises of the system.

In the scholarship on legal indeterminacy, scholars often conflate the purely logical notion of underdeterminacy with the stronger, justificatory sense. Both CLS writers and liberals like Dworkin seem to assume that if a system of laws is underdeterminate in sense (1), then it is rationally indeterminate in sense (2) as well: on this view, underdeterminacy logically entails lack of justification. But it is a serious mistake to conflate the two. Where multiple conclusions are derivable from a single set of premises, each conclusion makes a claim to rational justification. Multiple conclusions entail unjustifiability only if one assumes a further principle of rational justification, which I will call the One Right Answer thesis: ${ }^{19}$

The conclusion of an argument is justified only if it follows uniquely from the set of premises.

The One Right Answer thesis embodies a dominant norm in many forms of theoretical argument and empirical investigation: ideally, even where investigators disagree in practice over the right answer, they will converge on

16. Solum, Lipkin, and Kress all argue for benign pockets of indeterminacy in the legal system. See Solum, supra note 5, at 494-95; Lipkin, supra note 5, at 610-17; Kress, Legal Indeterminacy, supra note 4, at 295-301.

17. See Kress, Legal Indeterminacy, supra note 4, at 296-97.

18. Kress argues that a legal system may still be "holistically" legitimate even if some pockets of law are rationally indeterminate in sense (2): "[D]eterminacy is neither necessary nor sufficient for legitimacy at the global level, and only rarely necessary or sufficient at the local or individual level." Id. at 295.

19. Cf. Ronald Dworkin, No Right Answer?, 53 N.Y.U. L. Rev. 1, 2 (1978) ("[I]n every case either the positive claim, that the case falls under a dispositive concept, or the opposite claim, that it does not, must be true even when it is controversial which is true."). 
one conclusion..$^{20}$ Since Socrates, the thesis of unique convergence has also been intimately connected with another feature of our conception of truth, that all true beliefs are consistent; thus inconsistent conclusions in a system of reasoning are a sign of serious factual or theoretical defect. ${ }^{21}$ Critics of an indeterminate legal order implicitly rely on the One Right Answer thesis when they take judicial disagreement and conflicting legal obligations as proof of rational incoherence in the legal order. They argue that if no one answer is correct, then no answer can be correct.

In the case of most scientific investigation, we interpret inconsistent or divergent conclusions as a sign that at least one of the researchers has erred, since we generally assume that there is only one "way" the natural world can be. ${ }^{22}$ Likewise, the discovery of contradictions reveals a deep flaw in mathematical or logical systems of formal reasoning. But it remains to be shown whether this very strong requirement or ideal of convergence and consistency applies to the legal domain in full force, or to the domain of practical reasoning about obligation and action in general. ${ }^{23}$ When baldly stated, the One Right Answer demand that results be unique and consistent represents, in Isaiah Berlin's terms, a controversial and utopian claim about normative justification and the metaphysics of value: all questions in the domain of value have but one answer, the answer is knowable, and all answers are compatible. ${ }^{24}$ But this is a claim whose falsity is felt in the individual's everyday experience of conflicting moral obligations and value claims, whose multiple forces are still felt even after further rational reflection and deliberation. Here we routinely reject the idea that if many answers are right, then no answer is right. The experience of moral conflict is a sign of maturity, an awareness of the complexity and depth of the values which claim our attention. A disagreement between two moral agents, or a dilemma confronted

20. Moreover, some proponents of this conception argue that such investigators will converge on that unique conclusion because it is correct. See DAVID WIGGINS, Truth, and Truth as Predicated of Moral Judgments, in NEEDS, VALUES, TRUTH 139, 149-51 (1987). In a more Kantian vein, Jürgen Habermas argues that the ideal of an objective world about which all speakers may reach consensus is built into every speech act, but he rejects the notion that such an ideal consensus could ever be realized in the actual world. See, e.g., JÜRGEN HABERMAS, The Unity of Reason in the Diversity of Its Voices, in POSTMETAPHYSICAL THINKING 115, 138, 144 (William M. Hohengarten trans., 1992).

21. See PlATO, Euthyphro, in EUTHYPHRO, APOLOGY, Crito 1 (F.J. Church trans., 2d ed. 1986) (assuming that inconsistent responses reveal ignorance of form of piety); cf. NICHOLAS RESCHER, RATIONALITY 82 (1988) (arguing that even in empirical investigations we may do better to tolerate inconsistencies in the hopes of maximizing the number of truths we discover).

22. Post-Kuhnian philosophers of science challenge this assumption of uniqueness and consistency, but it seems safe to say that it continues to govern scientific practice. See, e.g., HiLARY PUTNAM, Why There Isn't a Ready-Made World, in REALISM AND REASON 205, 228 (1983) ("There is, then, nothing in the history of science to suggest that it either aims at or should aim at one single absolute version of "the world."').

23. This is not meant to beg the question of whether there is a coherent distinction between facts and values, or what form such a distinction might take. For the inclusion of legal reasoning within the general field of practical reasoning, see JOSEPH RAZ, PRACTICAL REASON AND NORMS 10-13 (rev. ed. 1990).

24. ISAIAH BERLIN, The Pursuit of the Ideal, in THE CROOKED TIMBER OF HuMANITY 1, 5-6 (Henry Hardy ed., 1991). This theme can be found throughout Berlin's work. 
by one agent, is evidence of rational engagement rather than cognitive defect or logical mistake. Thus a genuinely rationalist ethics rejects the One Right Answer thesis.

This Note argues that rational justification is compatible with divergence and conflict in the law as well. A sophisticated awareness of legal complexity and disagreement need not drag us down into Descartes' whirlpool. Instead, we may learn from the legal skeptics a more valuable-and more radical-lesson: a legal system is healthiest when there is conflict and dissent among its claims, because even irresolvable conflict is a sign of energy and attention. So long as the experience of pervasive conflict does not cause us to lose our commitment to reasoning in its many forms, continued public dissent and debate can be the legacy of skepticism.

\section{SEMANTIC INDETERMINACY IN THE LAW}

Human discourse's inherent semantic indeterminacy has led legal scholars to advance highly skeptical claims about the possibility of rational justification in the law. Many of these claims derive from difficult and technical philosophical arguments of Ludwig Wittgenstein and W.V.O. Quine; others simply reflect the vagueness and contextuality of our familiar forms of speaking. This Part argues that while considerations of vagueness do generate a form of indeterminacy and should be taken seriously, they do not thereby undermine the justifiability of legal conclusions. While semantic indeterminacy shows that the norms of truth and convergent conclusions are inappropriate aspirations for legal systems, rational argument and justification remain live possibilities.

\section{A. Vagueness and Cluster Concepts}

Vagueness is an ineradicable feature of our everyday language, and its pervasiveness in the law is the most commonly invoked reason for thinking that the law is indeterminate. Though we seem to have a firm intuitive grasp of what it means to describe, for example, compensation as "fair" or a form of behavior as "harassment," we are hard-pressed to decide in borderline cases whether a certain amount is truly fair or a particular act genuinely constitutes harassment. In such cases, we have trouble assessing the truth of sentences like " $\$ 320$ is fair consideration for a possible gain of $\$ 10,000$ "25 or "Displaying nude photographs constitutes harassment." ${ }^{\text {"26 }}$ The problem is not evidentiary inadequacy -more investigation cannot settle the issue. In philosophers' terms, there is simply no "fact of the matter" whether the term applies, or whether

25. See Embola v. Tuppela, 220 P. 789 (Wash. 1923).

26. See Baab v. AMR Servs. Corp., 811 F. Supp. 1246, 1262-64 (N.D. Ohio 1993). 
sentences employing it are true or false. Or, in H.L.A. Hart's familiar phrase, while we are often clear about the "core" application of a term in familiar contexts, we will be necessarily unclear about cases falling under its "penumbra of uncertainty."27 To the (very large) extent that a legal system employs vague terms and general concepts, it shares in the indeterminacy of natural language. Indeed, the problem is particularly acute in the law, as actors try opportunistically to skirt the boundaries of canonically accepted usage.

Two different sorts of semantic indeterminacy are at work in vague language. First, some terms, like "bald" or "reckless," are vague in application even though their meaning is quite determinate..$^{28}$ We know what "reckless" means. We also know that it truly describes driving 90 m.p.h. in a school zone. But what about driving 55 m.p.h. on the highway in the rain? In this type of borderline case, the applicability of the term, and the truth-value of sentences asserting it, is indeterminate. ${ }^{29}$ Even the apparently unproblematic terms "man" and "woman" may give rise to uncertainty in some circumstances, as in the case of transsexuals. ${ }^{30}$

Another set of terms, brought to philosophers' attention by Wittgenstein, presents a different form of vagueness. These terms, sometimes called "cluster" or "family resemblance" concepts, categorize objects or practices that bear some relation to one another yet share no distinctive set of common features. There is no unitary definition of such a category term, no rule for picking out which things fall within its extension. To use Wittgenstein's famous example:

Consider for example the proceedings that we call "games". I mean board-games, card-games, ball-games, Olympic games, and so on. What is common to them all? ... For if you look at them you will not see something that is common to all, but similarities, relationships, and a whole series of them at that. ${ }^{31}$

27. H.L.A. HART, Positivism and the Separation of Law and Morals, in ESSAYS IN JURISPRUDENCE AND PHILOSOPHY 49, 63-64 (1983).

28. Vague terms such as "short" or "fast," which are often classed as "attributive adjectives," present an additional problem, since their application is relativized to a (usually implicit) comparison class. A wait may be short for the D.M.V. but long for McDonald's; 3 m.p.h. may be a fast walk but a slow run.

29. In a like manner, vague predicates also generate paradoxes in a language. Though we may class only slightly different objects under the same predicate, incremental differences can aggregate to the point that we commit ourselves both to applying the predicate and denying its application. The ancient "Sorites" or heap paradox is one example: one grain of millet does not constitute a heap, nor do two, nor generally does something which is not a heap plus one grain constitute a heap; yet at some point a heap must have been constituted. The classic discussion of vagueness and paradox is MICHAEL DUMMETT, Wang's Paradox, in TRUTH AND OTHER ENIGMAS 248 (1978). For an interesting discussion of the paradoxes, see Jonathan Lear, Leaving the World Alone, 79 J. PHIL. 382, 393-97 (1982).

30. See, e.g., In re Ladrach, 513 N.E.2d 828 (Ohio P. Ct. 1987) (determining status of transsexual for purpose of issuing marriage license).

31. LUDWIG WITTGENSTEIN, PHILOSOPhICAL INVESTIGATIONS $\S 66$ (G.E.M. Anscombe trans., 3d ed. 1958); see also id. at $\S \S 67,77$. 
Problems arise not in the ordinary course of our application of such familyresemblance terms (say, to Monopoly or baseball) but only when we are presented with new cases that share some features of canonical members yet differ importantly as well (like Three Card Monte). To take Hart's example, "vehicle" plainly groups autos and motorcycles, but does it include bicycles? ${ }^{32}$ One might answer one way in a park and another in downtown Shanghai. Likewise, the notion of "sexual harassment" groups a wide range of behavior, and its application is surely closely tied to contextual expectation as well. As with vague terms like "reckless," cluster terms are often more appropriately applied to some candidates than to others, but in many cases there is no criterion that decides the matter.

It is clear why vague terms and cluster concepts are commonly seen as a problem for legal justification. In order for a syllogistic inference to be sound, it must be possible to settle the truth of the minor premise and hence to decide whether the vague term in the minor premise applies. ${ }^{33}$ If a judge's conclusion does not follow by logical inference, the skeptic argues, then it must rest on something else: a brute choice to include (or exclude) the particular case under the general rule. So a judge applying a law containing vague terms is not and cannot claim to be constrained by the law. Hart emphasizes this point, arguing that in cases of penumbral application, judges must leave rules behind and exercise their "discretion," invoking general political considerations. ${ }^{34}$ Hart is comfortable with this possibility as long as a judge's discretionary choice could be justified by moral and political norms. But Hart's approach invites a criticism raised by Dworkin as well as by legal skeptics: however sensible the judge, why should that unelected individual exercise political authority on the basis of policy considerations typically left to the legislature ${ }^{35}$ The judge's particular exercise of discretionary power does not transmit the authority of public rules. Hart's reliance on discretion also places a burden on the political or moral character of judges, leaving them to search their souls when the law falls silent.

Vague terms cannot be eliminated from a legal system. Although physicists and mathematicians are relatively free to avoid terms like "big" or "round," lawmakers cannot eliminate vague evaluative descriptions or references to social practices and artifacts. Terms like "fair," "reckless," "vehicle," and "harassment" play a necessary role in the law. True, where vagueness is too gross, as in the infamously vague vagrancy statute of Papachristou $v$. City of

32. HART, supra note 27 , at 63 .

33. In logic, an argument is sound only if its premises are true and its conclusions follow as a matter of logical consequence; a legal argument admitting vague terms will have premises without truth-values, and hence will fail to meet the logical standard of soundness.

34. H.L.A. HART, THE CONCEPT OF LAW 128, 132 (1961).

35. DwORKIN, Hard Cases, supra note 4, at 84 . 
Jacksonville, ${ }^{36}$ the elimination of some ambiguity may be both desirable and possible. But some vagueness will necessarily remain, and legal arguments will necessarily rely on the use of semantically indeterminate terms. If the skeptic is right, the limits of the law's language are the limits of its legitimate authority.

The skeptic serves us well by drawing our attention to the contestability of judgments about vague terms. If judgments using vague terms never have a determinate truth-value, then we must question claims that a word like "reckless" must be applied in a certain way. But even if such judgments cannot aspire to determinacy, they can aspire to rational justification, and public authority can still be transmitted along the chain of reasoning. Note that a great deal of the puzzlement concerning vague terms arises out of undue abstraction from their context of use. With the addition of context, we can argue over the assertibility of a term and thereby sharpen the boundaries of its application in the individual case, even if we cannot say that the conclusion is determinately true, but only that it is supported by solid reasons. To return to the example of recklessness, the sentence "Driving 55 m.p.h. in a rainstorm on the highway is reckless," can be more or less well supported where there is contextual specification of rain, road surface, and traffic intensity. The sentence remains indeterminate, but can now function in an argument or justification. ${ }^{37}$ Similarly, the term "fair" has too little determinate content to settle in the abstract the question of whether a $\$ 320$ claim stake is fair consideration for a promise of $\$ 10,000$. Our ultimate decision may be contestable, but it is the function of argument and context to render that decision defensible. When we consider the question in the context of typical risks borne by prospectors and investors, we may sharpen the boundaries of the term, looking at whether the promisor was coerced or incompetent, and whether such a rate of return constitutes a fair return on an investment or a usurious payment on a loan. ${ }^{38}$ Rather than putting an end to rational justification, the vagueness of language creates a need for it.

\section{B. Wittgenstein, Rule-Following, and Indeterminacy}

Wittgenstein's discussion of the phenomena of vagueness and cluster concepts constitutes only the surface of his criticism of a conception of language that treats it as a system of rigidly constraining rules. In the Philosophical Investigations he offers a deeper argument against the view of language shared by empiricism and Platonic idealism: the view that the capacity to employ a linguistic term involves grasping a mental image or

36. 405 U.S. 156, 162 (1972) (striking down vagrancy statute on grounds of vagueness).

37. See DUMMETT, supra note 29 , at 257.

38. See Embola v. Tuppela, 220 P. 789 (Wash. 1923). 
concept and employing it to pick out all and only those things that have the features of the mental image. For example, this view explains the proper use of the word "chair" by referring to the speaker's knowledge of the rule for using that word, and it conceives of this rule of use as the word's meaning. Against this view, Wittgenstein argues that the very notion of concepts or rules can neither explain a speaker's capacity to use words in novel contexts, nor justify one's judgments of their applicability. Legal theorists have seized upon Wittgenstein's argument in an attempt to show that any set of legal rules-in this case literal rules, not concepts-can neither explain nor justify any particular adjudicative use made of them. ${ }^{39}$

Briefly, Wittgenstein argues as follows: the model of language as rules neither explains nor justifies our use of words in a determinate and normative manner-our capacity, as Wittgenstein puts it, to "go on" correctly applying words to things in the world. ${ }^{40}$ First, the model of language as rules fails to explain linguistic capacity because rules themselves are inert; they lack a specified mode of application. For example, a speaker who has the rule "apply 'red' to all things with this color" must have a means of interpreting the rule, of understanding the concept "apply" and when something looks like "this." The explanation of language use as rule-following leaves unexplained how the rules themselves are grasped and applied. It does no good to posit another rule governing the interpretation of the original rule, since such a rule of interpretation must itself be interpreted. And so on, ad infinitum. Ultimately, a psychological capacity of application must explain the use of words, and this capacity cannot itself be explained by a model of rules for fear of regress. ${ }^{41}$

For a related reason, the model of language as rule-following cannot justify our use of words because inert rules cannot provide criteria for deciding when a particular application of a word is appropriate. As noted above, a rule leaves open how it is to be applied in the absence of a psychological capacity of a noninterpretive nature. As a result, no rule can settle the question of whether a speaker is in fact "going on" in the same way each time she uses a word-that is, whether her present application of a word accords with her own past usage. Wittgenstein argues that an indefinite number of rules could

39. Discussions of the implications of Wittgenstein for jurisprudence began with Charles Yablon's review of SAUL A. KRIPKE, WITTGENSTEIN ON RULES AND PRIVATE LANGUAGE (1982). See Charles M. Yablon, Law and Metaphysics, 96 YALE L.J. 613 (1987) (book review). See also the collection of essays discussing the use of Wittgensteinian arguments in legal theory in CAN. J.L. \& JURIS., July 1990, especially Brian Bix, The Application (and Mis-Application) of Wittgenstein's Rule-Following Considerations to Legal Theory, CaN. J.L. \& JURIS., July 1990, at 107; Andrei Marmor, No Easy Cases?, CaN. J.L. \& JuRIS., July 1990, at 61; and Frederick Schauer, Rules and the Rule-Following Argument, CAN. J.L. \& JURIS., July 1990, at 187. Other sources include Brian Langille, Revolution Without Foundation: The Grammar of Scepticism and Law, 33 MCGILL L.J. 451 (1988); Tushnet, supra note 3, at 822-23; and D'Amato, Pragmatic Indeterminacy, supra note 3 , at 152 n.16.

40. WrTTGENSTEIN, supra note $31, \S \S 151,185$ (discussing the ability to "go on" in generating a sequence of numbers).

41. See id. $\$ \$ 84-87,139-41,198-99$. 
account for any given pattern of word usage in the past, but that many of these rules will disagree on the correct use of the word on future occasions. If following any of those rules can make true the claim to be "going on in the same way," then the crucial normative notion of sameness of meaning is drained of its content. ${ }^{42}$ In Wittgenstein's words, "no course of action could be determined by a rule, because every course of action can be made out to accord with the rule." 43 A speaker-or a judge-could only trivially claim to be justified in any particular usage of a term. ${ }^{44}$

Because of this apparent "paradox" of rule-following, Wittgenstein proposes a form of linguistic capacity that does not simply consist of the application of rules. ${ }^{45}$ Wittgenstein describes language use as a "technique" or a "custom" whose basis is not reflective application, but something more like habit, like nonintellectual training and acting. ${ }^{46}$ We acquire language through our nonreflective "acting, which lies at the bottom of the languagegame." ${ }^{37}$ While a purely intellectual reliance on rules leads to the paradox of indeterminate application, language use that is grounded in habit and disposition ensures normativity without the paradoxes of conceptual mediation. As Stanley Cavell describes it, our capacity to use words correctly or incorrectly, such that normative continuity is preserved, is grounded in our sharing

routes of interest and feeling, modes of response, senses of humor and of significance and of fulfillment, of what is outrageous, of what is similar to what else, what a rebuke, what forgiveness, of when an utterance is an assertion, when an appeal, when an explanation-all the whirl of organism Wittgenstein calls "forms of life."48

42. Id. $\S \S 143-49,185-89,201$. This is essentially the interpretation/argument put forward by KRIPKE, supra note 39; the argument also appears in Tushnet, supra note 3, at 821-24; and D'Amato, Pragmatic Indeterminacy, supra note 3, at 173-75.

43. WITTGENSTEIN, supra note $31, \S 201$.

44. Note that, if sound, the argument is not just restricted to the use of predicates, but extends to all parts of discourse, including names and logical connectives. See COLIN MCGINN, WITTGENSTEIN ON MEANING 141-42 (1984).

45. Wittgenstein writes:

It can be seen that there is a misunderstanding here from the mere fact that in the course of our argument we give one interpretation after another; as if each one contented us at least for a moment, until we thought of yet another standing behind it. What this shews is that there is a way of grasping a rule which is not an interpretation, but which is exhibited in what we call "obeying the rule" and "going against it" in actual cases.

WITTGENSTEIN, supra note $31, \S 201$. For a richer interpretation of Wittgenstein's positive proposal, see the essays collected in WITTGENSTEIN: To FOLLOW A RULE (Steven H. Holtzman \& Christopher M. Leich eds., 1981); and MCGINN, supra note 44.

46. WITTGENSTEIN, supra note $31, \$ 199$.

47. LuDWIG WITTGENSTEIN, ON CERTAINTY § 204 (G.E.M. Anscombe \& G.H. von Wright eds., Denis Paul \& G.E.M. Anscombe trans., 1977).

48. STANLEY CAVELL, The Availability of Wittgenstein's Later Philosophy, in MUST WE MEAN WHAT WE SAY? 44, 52 (1969). This passage is helpfully elaborated and explored in John McDowell, NonCognitivism and Rule-Following, in WITTGENSTEIN: To FOLLOW A RULE, supra note 45, at 141, 148-51. 
In Wittgenstein's view, our capacity to communicate functions against a background of what he calls our "natural history,"49 which includes things like our natural tendency to react to someone's pointing (a gesture that lies at the heart of much language-learning) by looking in the direction from wrist to finger, rather than from finger to wrist, ${ }^{30}$ or like our shared dispositions to identify colors and to distinguish similarly between object and context. Though we may be inclined to cite a rule of use to justify our applications of a word, and though we may even revert to a further rule of interpretation to justify the way in which we apply the first rule, this series of justifications must at some point terminate in something that is not a rule, but simply a propensity to act.

However, Wittgenstein's solution to the paradox creates a new pressure point for the skeptic. If the correctness of a particular use of a word is not a function of its meaning, but instead expresses the natural tendencies of a community of users, the question immediately arises: who makes up-or dominates in-that community, and how "natural" are their dispositions? The ideal of the rule of law insists that judges apply a set of public rules in particular cases. If that application were at bottom a matter of conformity to the community's dominant dispositions, then the ostensible value of legal justification would be reduced to the expression of the interests of a judicial elite. In that case, judges' conformist decisions might be entirely predictable, but could not be justified in a nontrivial way on the basis of a set of public rules.

Our conception of what it means to use words correctly must adapt to meet Wittgenstein's challenge. Yet it would be too hasty to conclude that his skeptical challenge completely eliminates substantive rationality from linguistic practice. ${ }^{52}$ Before reaching this conclusion, the skeptic must show that linguistic correctness is nothing more than brute conformity. But this claim seems to confuse conditions of use with use itself, to confuse the artist's palette with the painting. Even if brute conformity with a communal practice is necessary in order to guarantee the regularity intrinsic to a communicative system, it does not follow that all aspects of that system must display the same kind of unreflective regularity. Rather, we might more plausibly conclude from

49. WITTGENSTEIN, supra note $31, \S 415$.

50. Id. $\S 185$.

51. See Scales, supra note 3 , at 1386-88. Langille fails to see that this picture of unreflective conformity is as troubling as the paradox it leaves behind. See Langille, supra note 39, at 494 . Scott Landers, in Wittgenstein, Realism, and CLS: Undermining Rule Scepticism, 9 LAW \& PHIL. 177 (1990), puts forward a similar argument, claiming against the Kripkean skeptic that rules are only indeterminate if prelinguistic conventional conformity is ignored. For a response that such conventionalism misreads Wittgenstein as well as fails to ease the skeptic's worry, see Bix, supra note 39, at 113-15.

52. Such a conclusion would in any case have astonished Wittgenstein, who notoriously insisted that philosophy could only be nonrevisionary, that is, that it should not change either our use of words or our understanding of our relation to the world. "Philosophy may in no way interfere with the actual use of language; it can in the end only describe it." WITTGENSTEIN, supra note 31 , $\$ 124$. For Wittgenstein himself, the legitimacy of the legal system could never have hinged on philosophical observations about linguistic capacity. 
Wittgenstein's argument that normativity and rationality are preserved, not eliminated, through appeal to the shared, natural patterns of affect and reaction which Wittgenstein calls our "form of life." that the habits that ground our activities of thought, argument, and investigation are themselves incompatible with rational reflection and justification. Higher-level rational justifications are not displaced by the need for conformity in some places, but continue to play a role among reflective language users. Without brute conformity in some judgments, human communication would indeed be impossible, but we can avoid the skeptical conclusion that communication is nothing more than brute conformity. ${ }^{54}$ Just as there must be agreement in units of measure in order for there to be disagreement over actual measurements, there must be agreement over some uses of words in order for there to be disagreement over their application in novel contexts. But no particular set of usages need be rendered immune to criticism and discussion. As Thomas Morawetz has emphasized, reflective disagreement and dispute presuppose a degree of agreement and conformity, but need not be wholly constrained by the conformity that exists. ${ }^{55}$

In fact, Wittgenstein's arguments create the very possibility of rational disagreement where unreflective conformity seems inadequate. Recall that in the model of language as rules, the applicability of a term is viewed as a decidable matter of truth or falsehood whose truth-value is determined by the rule of use. In such a model, disagreement over use could only reveal that at least one party to the disagreement had failed to grasp the rule correctly. In a Wittgensteinian conception of language, however, where reflective rules or unreflective habit fail to determine the applicability of the term, reason can and must supply guidance. Parties to a disagreement about language use can therefore look to the techniques of argument and persuasion to ground their different positions about the assertibility of a term. Furthermore, a Wittgensteinian conception of language opens up the possibility of ideological critique in a way that the traditional conception of language forecloses. If, for example, we reflect on our usage of the term "harassment," we may come to distinguish what is purely conventional from what is rational in our refusal to include the display of nude photographs within the scope of "harassment"-and we may thereby uncover a convention of blindness to a form of inflicted suffering. Philosophical and practical examination of language

53. Id. § 241 .

54. See BERNARD WILLIAMS, Wittgenstein and Idealism, in MORAL LUCK 144, 151-53 (1981) (interpreting Wittgenstein as giving "transcendental" account of conditions for community's employment of language rather than "empirical," or naturalistic and causal, account of how language functions).

55. Thomas Morawetz, Understanding Disagreement, the Root Issue of Jurisprudence, 141 U. PA. L. Rev. 371, 383-98 (1992); see also Thomas Morawetz, The Epistemology of Judging: Wittgenstein and Deliberative Practices, CAN. J.L. \& JURIS., July 1990, at 35 (arguing that capacity for disagreement presupposes massive agreement). 
use can liberate us from the bonds of habit when those habits are taken up in and transformed by reflection. ${ }^{56}$

The landmark due process case of Goldberg v. Kelly ${ }^{57}$ provides an example of how even quite settled semantic conventions can be destabilized through rational reflection and argument. Two central semantic issues were involved in the decision as to whether New York's Department of Social Services had deprived John Kelly of due process of law by terminating his welfare payments without a prior hearing. First was the question of whether welfare benefits were to be regarded as a form of "property." Clearly, welfare benefits are unlike real property; but so, for that matter, are patents and copyrights, or water rights and claim stakes. "Property" is a cluster concept, and it would be a mistake to suppose that there is any rule picking out what falls under its extension. Although Justice Brennan might have accepted that, as a matter of conventional usage, welfare payments are not considered property, he argued (and referred to Charles Reich's more extended argument) that the emergence of such new forms of entitlements as franchises, state licenses, and government subsidies force us to reconsider the sedimented use of the term "property." In dissent, Justice Black emphasized the difference between welfare payments and protected entitlements: he conceived of the former as gratuitous promises and therefore beyond the scope of protected promissory obligations. ${ }^{59}$ Both Justices employed analogical reasoning and argued for consistency with relevantly similar cases, for welfare benefits are clearly like some things protected by the Fourteenth Amendment (civil service positions, subsidies), but also like some things not so protected (charitable promises, gratuities).

The second issue was whether termination of Kelly's property interest in his welfare benefits without a prior hearing satisfied the requirements of due process. Brennan argued that the anticipation of "grievous loss" should influence the due process determination, and he concluded that the loss associated with the termination of welfare benefits was severe enough to require a prior evidentiary hearing. ${ }^{60}$ In response, Black argued that where there is an "ongoing legal relationship," termination of a disputed benefit need not be preceded by a hearing, especially where the receiving party is judgmentproof. ${ }^{61}$ Again there is no fact of the matter. Neither Justice could claim to be using the words "property" or "due" in the uniquely correct way. But it

56. Bix emphasizes the compatibility of a Wittgensteinian account of language with reflective criticism of the conventional base of legal language. See Bix, supra note 39, at 112-15.

57. 397 U.S. 254 (1970).

58. Id. at 262 n.8. Brennan quotes Charles Reich, Individual Rights and Social Welfare, 74 YALE L.J. 1245, 1255 (1965), and cites Reich's pathbreaking article, The New Property, 73 YALE L.J. 733 (1964).

59. 397 U.S. at 275, 277-78 (Black, J., dissenting).

60. Id. at 263 (quoting Joint Anti-Fascist Refugee Comm. v. McGrath, 341 U.S. 123, 168 (1951)

(Frankfurter, J., concurring)).

61. Id. at 277-78 (Black, J., dissenting). 
would be wrong to conclude that the decision reached was rationally unsupported or discontinuous with the general prior "rule" for applying the Fourteenth Amendment. The arguments Brennan and Black put forward and the reasons they adduced in support of their positions provide the requisite form of justification, despite the inherent indeterminacy of the issue.

Skeptics worry that judges' decisions are biased to the extent that they are governed by judicial conventions and arbitrary to the extent that they are not so governed. Conventionalists like Hart worry that when (linguistic) conventions break down, judges' decisions are unconstrained by linguistic standards. ${ }^{62}$ But the way in which Wittgenstein undermines the distinction between conventional rule-following and the projection of a word into a new context refutes both positions. If the use of a word is never just the application of a rule, then the distinction Hart and the skeptics draw between canonical usage and projection into the penumbrae of possible applications is one of degree, not kind. ${ }^{63}$ The application of a term is never utterly conventional, nor is its projection ever utterly arbitrary. Instead, applications and extensions are rational, albeit usually habitual, evaluations of the meaning of a term with reference to conventions that are both stable and evolving. If the habits that ground the core usage of a term are susceptible to rational scrutiny, then it is true both that the apparently settled core is a possible subject for rational critique and that the disputed penumbral application is a candidate for justification. In the Goldberg example, neither rights to real property nor rights to welfare checks are simply entailed by the proper use of the word "property"; both must be justified if they are to claim legal authority.

Another example of the rational criticism of accepted word usage is the shifting interpretation of the Commerce Clause between Hammer $v$. Dagenhart ${ }^{64}$ and United States v. Darby ${ }^{65}$ as the Court struggled over the scope of the term "commerce." The two decisions were separated by an important transformation in the Court's conception of the national economy. Rational continuity in the rules for applying the term allowed the later Court to challenge the conventions of the earlier. Permissiveness in the rules for applying the term allowed the Justices to shift its extension. The 1918 Court declared that "[t]he making of goods and the mining of coal are not commerce." ${ }^{166}$ In 1941, however, the Court held that the manufacture of goods destined for interstate shipment was within the scope of the "commerce" which Congress has the power to regulate. ${ }^{67}$ What this shift shows is not the

62. See supra notes $34-35$ and accompanying text.

63. Although Hart himself does not conceive of language as a system of rules, the sharp distinction he draws between core usage and penumbral applications is a feature of the rule-based model that Wittgenstein criticized.

64. 247 U.S. 251 (1918).

65. 312 U.S. 100 (1941).

66. Hammer, 247 U.S. at 272.

67. Darby, 312 U.S. at 122-23. 
irrationality of linguistic usage in the law, but the openness of such legal issues to rational debate. As in Goldberg, the justifications offered will involve a broad range of techniques of reasoning, such as invoking easily determinable non-borderline cases for their relevant similarities and differences with the disputed application, or invoking analogous examples from other domains. Initial judgments can then be revised in the face of competing considerations. If all reasons and arguments offered are unconvincing, then we may have reason to conclude that the dispute is, in fact, intractable to rational settlement. But the mere fact of persistent conflict as we cantilever out from the core of settled use is no reason to conclude that all applications are ultimately arbitrary. ${ }^{68}$ Precisely to the extent that the considerations offered have logical force, the decision about the applicability of the general rule can be justified.

The skeptic who dismisses the role of argument in supporting and transforming language use relies on a cramped view of rational discourse. We do better to take a more progressive lesson from the skeptic: challenge canonical usage and dissent from received wisdom. Far from indicating the futility of argumentative engagement, examination of linguistic indeterminacy shows why such engagement is necessary. Semantic indeterminacy should not throw us into the whirlpool of despair, but it does give us reason to swim against the current of linguistic orthodoxy.

\section{BACKGROUND DEPENDENCE AND ARGUMENTATIVE INDETERMINACY}

Part II argued that legal skeptics are right to claim that the language of the law is semantically indeterminate, in the underdeterminative sense that the judgments of the applicability of many terms or rules are persistently open to debate. Although supplementation by context can help to focus debate and provide supportive reasons, semantic judgments will often not be susceptible to definitive proof or the assignment of a truth-value. This Part takes up two different, non-semantic sources of legal indeterminacy: the dependence of legal conclusions on unargued "framings" or characterizations of background facts; and the tendency of nondeductive reasoning techniques to license multiple conclusions.

\section{A. Background Dependence and the Theory-Ladenness of Facts}

Even where terms are not vague, language is beset by a form of indeterminacy that stems from the dependence of our discourse upon an assumed background of factual assumptions. Unlike the languages of math and

68. See Simon Blackburn, Reply: Rule-Following and Moral Realism, in WITTGENSTEIN: TO FOLLOW A RULE, supra note 45 , at 163, 176-77 (arguing that divergence need not be simply a matter of taste, but is subject to rational settlement). 
science, where assertions are cast so as to be true or false for all times and all places, many of the sentences we use are implicitly relativized to a time and a place. Even if the context is unstated, we are typically able to use environmental clues or conventions in order to eliminate possible ambiguities and pick out the event or location in question. For example, the assertion "It is raining" has no determinate truth-value unless the place of its utterance is specified or presupposed. Similarly, the sentence "Visiting professors can be difficult" will remain ambiguous, and hence indeterminate, unless contextual clues allow one to distinguish between its two senses. ${ }^{69}$

This is a variation on a theme familiar from Quine and Nietzsche as well as from much twentieth-century philosophy of science: "Facts" are theoryladen, and even our apparently bare experience is always affected by the conceptual apparatus we bring to it. ${ }^{70}$ Our empirical understanding is mediated by concepts and interpretations whose fluidity reflects our changing theoretical and practical interests. To the extent that the particular meaning or truth-value of a sentence depends upon the audience's presuppositions, shifts in the tacitly understood background will change the applicability of a term or rule. If a judge supplies the context for the interpretation of a legal rule, and that contextual supplement is decisive, then the judge's conclusion will have been driven directly by the background he assumes. The general rules are idle in determining the result.

This problem of background dependence arises chiefly with factual characterizations rather than interpretations of general rules. The defensibility of a characterization of the defendant's driving as reckless depends on background assumptions concerning, among other things, the driver's skill or the density of traffic. Mark Kelman, elaborating on a point made by Karl Llewellyn, has shown theoretically that in the criminal law these factual characterizations are critical to the judge's decision yet are often unstated by the judge. As Kelman puts it: "Legal argument can be made only after a fact pattern is characterized by interpretive constructs. Once these constructs operate, a single legal result seems inevitable, a result seemingly deduced on

69. Philosophers and linguists call the contribution context makes to meaning and truth "pragmatics"; "radical pragmatics" is the view that context always makes an essential contribution to the meaning or truth-value of a sentence. See generally DAN SPERBER \& DIERDRE WILSON, RELEVANCE: COMMUNICATION AND COGNITION 10-15 (1986); PRAGMATICS: A READER (Steven Davis ed., 1991). The locus classicus of the philosophical discussion is PAUL GRICE, Logic and Conversation, in STUDIES IN THE WAY OF WORDS 22 (1990).

70. These are persistent themes in Quine and Nietzsche. See, e.g., WILLARD V.O. QuINE, Two Dogmas of Empiricism, in FROM A LoGICAL POINT OF VIEW 20 (2d rev. ed. 1961); FRIEDRICH NIETZSCHE, THE WILL TO POWER $\$ 481$ (Walter Kaufmann ed., Walter Kaufmann \& R.J. Hollingdale trans., 1968) ("No, facts is [sic] precisely what there is not, only interpretations. We cannot establish any fact 'in itself': perhaps it is folly to want to do such a thing."); see also HILARY PUTNAM, REALISM WITH A HUMAN FACE 26-29, 96-104 (1990) (emphasizing "conceptual relativity" of all characterizations of "reality"); RICHARD RORTY, PHILOSOPHY AND THE MIRROR OF NATURE (1979) (arguing against coherent epistemological distinction between knowing subject and object of knowledge). 
general principle."71 Kelman's examples of such variable interpretive constructs include whether the time frame of an incident is understood to be short or long, whether actions are thought of as disjointed or as part of a unified enterprise, whether the defendant's intent is considered narrowly or broadly, and whether the defendant is regarded as an individual or as part of a conspiratorial group. ${ }^{72}$ If police officers take Martin onto a public highway when he is intoxicated and then charge him with violating a statute prohibiting such conduct, the crucial issue of voluntariness will hinge on whether one interprets the time frame of the incident to include the defendant's original-presumably voluntary -choice to drink..$^{73}$ Yet the choice of time frame, Kelman argues, is the outcome of an "arational" interpretive construction of the facts, whose significance is repressed so that the latent political issues do not surface. ${ }^{74}$

Kelman is surely right that many legal arguments hinge on characterizations of the facts, and that the "correct" way of framing the facts will be a matter of dispute, probably with political or ideological resonance. Apparently natural or neutral ways of characterizing events may conceal bias and distortion. It is an important philosophical point that any state of affairs may be described in a number of ways, each with a strong claim to representational accuracy, but each reflecting different interests. "Hillary Rodham Clinton is directing the revision of health care" and "The President's wife has a massive hand in domestic policy" are different descriptions of the same state of affairs, but probably evoke different reactions. Kelman's error, however, lies in his too hasty move to the skeptical claim that any chosen characterization of the facts must be "arational" or "nonrational." Dramatically, he writes that "[i]t is illuminating and disquieting to see that we are nonrationally constructing the legal world over and over again; it is a privilege to discern some structure to this madness."

The conclusion that "madness" rests at the heart of law is surely not warranted by the observation that legal arguments rest on implicit factual presumptions. As a purely trivial point, advocates argue thoroughly for factual characterizations, even if the judicial opinion sometimes acknowledges only the conclusions drawn from such arguments. More importantly, Kelman's

71. Kelman, Interpretive Construction, supra note 3, at 593; KARL LLEWELLYN, THE BRAMBLE BUSH 80 (7th prtg. 1961) (arguing that evidence requires "interpretation"); see also Kairys, supra note 3, at 17 ("[E]ven the facts relevant to a particular controversy (largely reduced to uncontroversial givens in law schools) are not capable of determination by any distinctly legal or nonpolitical methodology. Law is surely politics by other means.").

72. Kelman, Interpretive Construction, supra note 3, at 594-96.

73. See Martin v. State, 17 So. 2d 427 (Ala. Ct. App. 1944) (holding that police action of removing inebriated defendant from his home to public highway fails to satisfy voluntariness requirement of criminal law).

74. Kelman, Interpretive Construction, supra note 3, at 600-16; cf. KELMAN, GUIDE TO CLS, supra note 3 , at 3 (stating that liberal thought systematically represses its internal contradictions).

75. Kelman, Interpretive Construction, supra note 3 , at 672 . 
suggestion that the factual characterizations we offer are unfounded or "arational" assumes implicitly a version of the One Right Answer thesis: either there is one way to characterize the world correctly, or there is no way to characterize it correctly. But Kelman has given us no reason to accept this claim; instead, he has given us reason to reject it. For if the various interpretations we make of the world are all we have, then a great deal is at stake in which interpretation we choose, and we should seek those interpretations which best satisfy our interests, be they interests of social justice or empirical prediction. Alternative and conflicting choices among characterizations of the same set of events can be governed and evaluated by rational reflection so long as the interests at stake are made clear. Kelman himself gives reasons both for and against thinking that Martin voluntarily violated the law against being intoxicated on a public highway, and these reasons can be assessed against a backdrop of further reasons concerning the type of behavior the society wants to regulate. ${ }^{76} \mathrm{Had}$ such reasoning taken place in court, Martin would have been well served.

Thus, Kelman's signal contribution lies in pointing out the implicit ideological bias in the characterizations of facts that form the basis for legal argument. Yet the very concept of ideological bias has force only if we assume a means of testing and correcting for it. Far from insulating factual premises from rational evaluation, the indeterminacy of facts invites rational scrutiny because it demands that any particular characterization of the facts be justified.

\section{B. Argumentative Indeterminacy}

Systemic indeterminacy may also result from reliance upon nondeductive forms of argument or techniques of reasoning. In many models of strictly deductive reasoning, the only permitted logical operations are those that lead to consistent conclusions. But judges and advocates often use nondeductive techniques of reasoning: they generalize from past experience, invoke vague moral and policy considerations, and argue for highly abstract interpretations of previous decisions. It is prima facie unlikely that these forms of reasoning will lead to consistent, much less univocal, results. For once the strawman of a purely syllogistic or mechanical jurisprudence is set aside ${ }^{77}$ and legal argument takes on some of the techniques of practical reasoning generally, the validity of its inferences is open to question in a way that strict deductive inferences are not. The skeptic challenges the move toward expanding the domain of legal argument: once the rigorous pretentions of precedential

76. Id. at $603-05,618-20$.

77. Cf. Unger, supra note 3, at 564 ("By formalism [legal liberalism] I do not mean ... belief in the availability of a deductive or quasi-deductive method capable of giving determinate solutions to particular problems of legal choice."). 
reasoning are deflated, the logical value of its "inferences" are newly open to doubt. $^{78}$

The problem for the nonskeptical legal theorist is to describe a framework of reasoning that avoids the pretense of pure deduction yet nonetheless transmits rational support along its inferential links. What forms beyond the rigidly syllogistic can legal reasoning take? Following Edward Levi, many scholars take the central form of legal reasoning to be reasoning by analogy. ${ }^{79}$ As we saw above, such a practice lies at the core of linguistic capacity generally. ${ }^{80}$ While the legalistic manner of distinguishing cases and adducing precedents may be more stylized, it should be no weaker logically than analogical reasoning in other domains. Richard Posner argues that legal reasoning is highly catholic, comprising a collection of many distinct techniques of practical reasoning in general. ${ }^{81}$ Legal reasoning also incorporates features of both means-end reasoning (as when a judge attempts to determine which remedy will best satisfy a party's need ${ }^{82}$ and what has been called holistic or "constitutive" reasoning (as when a judge is called on to determine the fairness of a set of procedures). ${ }^{83}$

Of course, legal reasoning should be more constrained than forms of theoretical and practical reasoning in some other domains; it should accord less weight to imaginative reenactment and role-playing, for example. But even imagination and sympathetic engagement play a significant role in legal reasoning without obviously delegitimating the court as a forum for rational argument. Indeed, the law privileges live over written testimony precisely because of its greater evidentiary value. ${ }^{84}$ Similarly, Justice Brennan is most persuasive in Goldberg when he evokes the concrete implications of terminating welfare benefits for recipients; his argument for more procedural

78. The strongest version of this thesis is by D'Amato, Deconstruction, supra note 3 , at 115 (" $\mathrm{A}$ decision in any case is reached by the brute force of majority rule. The majority was not constrained by law to reach the decision it reached, as the minority well knows."); see also Kairys, supra note 3, at 14; Peller, supra note 3, at 1155; MARK TUSHNET, RED, WHITE, AND BLUE 51 (1988) (arguing that precedential reasoning has no independent logical force); Tushnet, supra note 3, at 822-23 (arguing that court decisions are only consistent when external institutional factors are taken into account).

79. EDWARD LEVI, AN INTRODUCTION TO LEGAL REASONING 1 (1949).

80. See supra Part II, Section B.

81. Posner, supra note 5 , at $843-48,858-59$.

82. See, e.g., Hart v. Community Sch. Bd., 383 F. Supp. 769 (E.D.N.Y. 1974) (determining proper remedy in complex school desegregation lawsuit), aff'd, 512 F.2d 37 (2d Cir. 1975).

83. See, e.g., Goldberg v. Kelly, 397 U.S. 254 (1970). On means-end and constitutive reasoning, see generally DAVID WIGGINS, Deliberation and Practical Reason, in NEEDS, VALUES, TRUTH, supra note 20, at 215 . To the extent that legal reasoning relies on such inferential techniques, its basic logical concept will be, in Herbert Simon's terms, "satisficing," rather than strict entailment, since any of a range of answers will satisfy the demands of reason. See HERBERT SIMON, REASON IN HUMAN AFFAIRS 90 (1983).

84. See FED. R. EVID. 804 (making exception to hearsay rule to allow admission of written depositions when declarant is unavailable as live witness); FED. R. CIV. P. 32(a)(3) (admitting deposition when witness is more than 100 miles from trial); $c f$. Cathaleen A. Roach, It's Time To Change the Rule Compelling Witness Appearance at Trial: Proposed Revisions to Federal Rule of Civil Procedure 45(e), 79 GEO. L.J. 81 (1990) (arguing that preference for live, in-court testimony should be relaxed in light of technological progress). 
protection for welfare recipients depends crucially on the deeply felt need of the recipient. ${ }^{85}$ And, despite Gary Peller's claim that the metaphysical presuppositions of the law of rape renders it blind to the experience of women ${ }^{86}$ Susan Estrich's work on the phenomenology of rape ${ }^{87}$ has had a distinct impact on judicial decisions as judges have become aware of previously hidden dimensions of the experience of victimization. ${ }^{88}$ In short, legal reasoning appears to encompass-to its credit rather than its detriment-many of the forms of reasoning found in other spheres, both theoretical and practical.

Finally, certain skeptics argue that an important distinction between abstract legal reasoning and contextual practical reasoning has been overlooked. ${ }^{89} \mathrm{~A}$ judge may use moral and political considerations in order to draw only rationally supportable conclusions, yet these moral and political justifications may be too loosely related to the narrower set of canonical legal reasons to satisfy the ideal of the rule of law. Dworkin tries to save the rule of law by rejecting the distinction between legal reasoning and practical reasoning; he argues that the ideal of the rule of law is best served by allowing moral and political reasons as well as conventional legal reasons to play a canonical role in legal argument. ${ }^{90}$ Less controversial is the view that judges who act on the basis of inappropriate reasons, be they moral or personal, are properly subject to criticism as judges. ${ }^{91}$ So long as judges are required to display fully their reasoning in reaching a decision, we can evaluate the strength of their arguments by relying on the same forms of argument that they use. There is no necessary reason for us to deprive the legal system of a full set of argumentative tools.

By demonstrating the multiplicity of possible descriptions and the underdeterminacy of arguments, the skeptic points to new dimensions in which rational argument is vitally important. Once the chimera of purely deductive argument has vanished, more generous argumentative techniques are sure to license a greater array of conclusions. Divergence is then not only to be expected; it is to be welcomed as proof of engagement with the full range of argumentative possibilities. In the law, justification must be seen as a function of the coherence of an argument, rather than of the univocal truth of its conclusion. Divergent conclusions following from different evidential bases or distinct techniques of reasoning are each individually justified. If alternative conclusions are possible, then renewed argument will always be useful, and

85. Goldberg v. Kelly, 397 U.S. 254, 261, 264 (1970).

86. Peller, supra note 3 , at $1190-91$.

87. SUSAN ESTRICH, REAL RAPE (1987); Susan Estrich, Rape, 95 YALE L.J. 1087 (1986).

88. See State ex rel. M.T.S., 609 A.2d 1266, 1274 (N.J. 1992) (citing Susan Estrich on importance of experience of "bodily integrity").

89. See, e.g., Kairys, supra note 3.

90. See generally DWORKIN, LAW'S EMPIRE, supra note 4; Dworkin, Hard Cases, supra note 4.

91. See infra text accompanying notes 97-101. 
received conclusions will always be subject to reexamination. Rational divergence invites the type of vigorous rational scrutiny that is best suited to exposing bias and hatred that may otherwise remain concealed within legal conventions.

\section{NORMATIVE INDETERMINACY}

We have seen that divergence and disagreement in legal decisions inevitably result from the indeterminacy of language and argumentation-while creating a necessary place for reason and argument in the law. In any reasonably complex or mature legal system, the substantive legal norms and rules themselves give rise to indeterminacy. In their permissiveness, their tendency to license a range of equally satisfactory decisions, such norms exhibit a benign form of indeterminacy. To the extent that the norms of the system conflict, the indeterminacy generated is more troubling. However, once the demand for convergence has been dropped, even divergence caused by conflicting norms and conclusions can be seen as consistent with the ideal of the rule of law. This Part argues that substantive conflict is, in fact, not a defect in a legal system, but a sign of its continuity with the plurality of public values the legal system embodies and mediates.

\section{A. Indifference and Buridan's Ass}

Nonlegal systems of practical reasoning-prudential, moral, and political-share an uncontroversial type of indeterminacy in the form of permissiveness: for any given fact-pattern, each of an indefinitely broad range of actions will satisfy the relevant standard of rationality. Permissiveness is a standard -indeed desirable-feature of a legal order as well, for the range of actions permitted by the system is a measure of the freedom of its subjects, at least to the extent that the freedom of some is not tantamount to the oppression of others. The rules and principles constraining judicial decisions underdetermine the final choice among a variety of possible decisions. Extralegal reasons must help determine the final conclusion. For example, judges are granted a form of discretion in sentencing offenders: the penalty bundle can contain varying amounts of community service, fines, and incarceration, as long as it serves the legal norms of efficacy and proportionality and is within sentencing minimums and maximums.

The relevant point is that once the range of judicial actions has been narrowed by consideration of the applicable norms and rules, the final decision is, in an important sense, arbitrary with respect to the operative legal reasons, 
yet still justified by the norms of the system. Like Buridan's Ass, ${ }^{92}$ the judge has no further legal reason to choose among actions which are, at the level of resolution of the legal system, normatively identical. This situation is familiar in moral theory, where a number of activities are typically picked out as morally acceptable, yet none is marked as morally best. Kantian-inspired deontological theories are centrally concerned with marking out a domain in which moral demands are silent after the agent has satisfied the demands of duty. ${ }^{93}$ At the same time, even a strict act-utilitarian who tries to pick out the utility-maximizing action will typically be indifferent among a range of actions, especially if information constraints are taken into account. ${ }^{94}$ Distinct choices (working in a soup kitchen, sending money to Oxfam) are describable within the system as morally identical (acting charitably). From this perspective, it may be said that the normative system is indeterminate at the level of action, but determinate at an appropriate level of abstraction.

Indeterminacy as indifference is not rational indeterminacy in the strong sense. Each member of the set of morally or legally permitted actions is justified by the public legal rules; underdeterminacy does not weaken the public authority of the actual decision. The significance of this uncontroversial point is little remarked. Yet it shows one way in which the One Right Answer thesis is plainly wrong. Indeterminacy in this sense is not a defect in the legal system and should in fact be considered a virtue, since it allows the decisionmaker the flexibility to accommodate particular circumstances. ${ }^{95}$ Nonetheless, there remains a significant worry associated with this form of indeterminacy or discretionary authority: because the decisionmaker is granted a range of choices, it is possible for him or her to indulge abhorrent biases when making the final choice. To take the most notorious example, in states that allow a sentence of execution or life imprisonment, poor and black defendants are sentenced disproportionately to death. ${ }^{96}$ The permissiveness of the legal standards leaves room for the individual and the systematic bias that is inherent in the social structure. Indeterminacy in the legal system allows

92. Buridan's Ass was the donkey imagined by medieval philosopher Jean Buridan. The donkey had no reason to choose between two identical bales of hay and so starved to death, unable to make a decision.

93. This feature of deontological theories is labelled an "agent-centered prerogative" in SAMUEL SCHEFFlER, THE REJECTION OF CONSEQUENTIALISM 14 (1982); see also THOMAS NAGEL, EQUALITY AND PARTIALITY 43 (1991) (arguing that Kantian theory permits a range of egalitarian political institutions). Note that Kant's own account of moral duties leaves very little room for personal projects; the agent's duty to seek out others' perfection and make their ends her own has the same potential to swallow up the agent's resources as much as the most demanding forms of utilitarianism. See IMMANUEL KANT, THE METAPHYSICS OF MORALS [386-88] (Mary Gregor ed. \& trans., Cambridge Univ. Press 1991) (1797).

94. The significance of uncertainty for utilitarianism is stressed in RuSSELL HARDIN, MORALITY WITHIN THE LIMITS OF REASON 2-9 (1988).

95. HART, supra note 34 , at $125-26$.

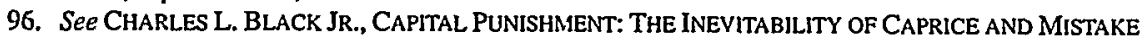
96-101 (2d ed. augmented 1981). Where juries decide the issue of capital punishment, the problem is rather different, for the law typically plays a considerably weaker role as constraint. 
hate to hide as rational decision, much as, in Nietzsche's eyes, a morality of duty hides the motive of resentment. ${ }^{97}$

The response to this objection is to acknowledge its claim as social criticism, and then meet it head on as a logical confusion. The flaw in a system of laws in which systematic bias has an effect is the bias itself, not the indeterminacy of the system. If, by hypothesis, any one of a set of choices is legally justified but only one is selected on the basis of abhorrent nonlegal reasons, then even that abhorrent choice retains its logical credential as legally justified. The minimal ideal of the rule of law is served whenever there is an appropriate relation between decision and grounds. Criticism of the political, moral, or social viciousness of the decision is a separate issue altogether.

This distinction should not encourage complacency about manifestations of systematic biases in the law or within discretionary authority. To the extent that the system of laws serves directly or indirectly to further racial, gender, or class inequalities, it is an appropriate subject for criticism and reform. ${ }^{98}$ And to the extent that those who occupy positions of legal authority act on the basis of any such bias, these authorities may also be criticized and corrected, however difficult such criticism may be in practice. The ideal of the rule of law is entirely compatible with such criticism.

In fact, to the extent that the crucial liberal norm of publicity is emphasized, ${ }^{99}$ the rule of law contains resources for avoiding the problem of discretionary bias, resources that are unavailable in modes of informal decisionmaking. ${ }^{100} \mathrm{It}$ is an implicit requirement of the rule of law that all grounds for a decision be displayed in the judicial opinion, so that the justificatory argument can be subject to public disagreement, dissent, and correction. Although the indeterminacy of legal reasons allows the operation of extralegal motivations to affect decisionmaking, such motivations must still be made public and subject to legal scrutiny. Otherwise, the ideal of publicity is violated. Once they are forced into the public sphere, such reasons can be evaluated to see whether they also fall outside the set of what John Rawls calls "public reasons," or those considerations which carry legitimate force in political or social argument by virtue of their coherence with public ideals. ${ }^{101}$ Such a set of public ideals can perform the role of constraining the argumentative possibilities without at the same time dictating univocal

97. Friedrich Nietzsche, ON the Genealogy of MoRals First Essay, $\$ \$ 10-17$ (Walter A. Kaufmann \& R.J. Hollingdale trans., Vintage Books 1989) (1887).

98. James Boyle urges a variety of "locally" critical pragmatism: social criticism should be directed against concrete injustices, not based on broad theories of ideology. James Boyle, The Politics of Reason, 133 U. PA. L. REV. 685, 773 (1985).

99. JOHN RAWLS, A THEORY OF JUSTICE 55-56, 133 (1971).

100. Owen Fiss makes a sustained argument against informal structures of adjudication. See Owen M. Fiss, Out of Eden, 94 YALE L.J. 1669 (1985); Owen M. Fiss, Against Settlement, 93 YALE L.J. 1073 (1984).

101. JoHN RAWLS, POLITICAL LIBERALISM 213-27 (1993). 
conclusions. We can then regard biased judgments as beyond the pale of public justification without relying upon an implicit ideal of convergence.

\section{B. Normative Conflict}

Indeterminacy as indifference demonstrates the compatibility of justification and certain kinds of divergence. However, contemporary legal systems are not only underdeterminative in this sense; they are also indeterminate insofar as they contain conflicting rules and norms that give rise to sharply conflicting conclusions. But it is a mistake to regard such conflict as a flaw in a legal system. This section argues that a legal system is healthiest, and most immune to the dangers of systematic bias, when conflict and dissent are pervasive.

CLS writers have attempted to show not only that peripheral legal rules may conflict with one another, but that conflicting ideals are deeply embedded in the law. ${ }^{102}$ Because of these conflicts, different judges can reason from different norms, each with an equal status within the legal system, and thereby arrive at very different conclusions. ${ }^{103} \mathrm{~A}$ moment's reflection should assure us that it would be both remarkable and terrible if this were not the case. A legal regime that did not encompass conflicting values would fail to recognize the multiple and conflicting sources of value that claim our moral and political allegiance.

There are two principal reasons to expect a legal regime to contain conflicting values. First, legal regimes represent the accretion of the goals and acts of political actors scattered over time, occupying different perspectives, responding to different circumstances, and motivated by different interests. Even on a quite strong interpretation of the efficiency thesis, ${ }^{104}$ any mature legal regime is likely to have a rich and varied set of norms as its basis in both common and statutory law, reflecting the heterogeneous interests and ideologies of the parties who have constructed it.

102. See generally Robert W. Gordon, Critical Legal Histories, 36 STAN. L. REV. 57 (1984) (marshalling arguments for incoherence of contemporary legal systems); KELMAN, GUIDE TO CLS, supra note 3 , at 3,15-113 (arguing that American law is beset by contradictions, including contradictions between commitment to mechanical rules and flexible standards, between value relativism and realism, and between free will and determinism); Duncan Kennedy, Form and Substance in Private Law Adjudication, 89 HARV. L. REv. 1685 (1976) [hereinafter Kennedy, Form and Substance] (arguing that values of individualist selfinterest and altruistic solidarity conflict in contract law); Duncan Kennedy, The Structure of Blackstone's Commentaries, 28 BUFF. L. REV. 209 (1979) [hereinafter Kennedy, Blackstone's Commentaries] (locating conflict between solidarity and individualism in common law); Unger, supra note 3, at 616-33 (arguing that contract law doctrine embodies conflict between ideals of freedom and interpersonal fairness).

103. Cf. Unger, supra note 3 , at 570 (" $[E]$ very thoughtful law student or lawyer has had the disquieting sense of being able to argue too well or too easily for too many conflicting solutions. Because everything can be defended, nothing can; the analogy-mongering must be brought to a halt.").

104. See, e.g., RICHARD A. POSNER, ECONOMIC ANALYSIS OF LAW 21 (3d ed. 1986) ("[T] law is best (not perfectly) explained as a system for maximizing the wealth of society."); George L. Priest, The Common Law Process and the Selection of Efficient Rules, 6 J. LEGAL STUD. 65 (1977) (arguing that efficient rules will tend to dominate inefficient rules as legal systems evolve). 
The second reason stems from the nature of value itself and reflects the relationship of a modern legal system to the broader set of public ideals. In Isaiah Berlin's words, it is the recognition that:

There are many objective ends, ultimate values, some incompatible with others, pursued by different societies at various times, or by different groups in the same society, by entire classes or churches or races, or by particular individuals within them, any one of which may find itself subject to conflicting claims of uncombinable, yet equally ultimate and objective, ends. ${ }^{105}$

This is a claim of normative pluralism, not relativism: values differ among cultures and individuals but are not reducible to culture or taste. Claims of value may be supported by reasons: we owe it to each other in cases of conflict to try to make intelligible the claims to which we respond. Thus, unlike a relativist, a pluralist can respect the choices of those pursuing divergent claims of the good while deploring those whose pursuits cannot be justified at all. This view is also a central theme of multiculturalism: appreciation of a diverse array of conflicting claims about the good is both possible and desirable in a humane political order. When skeptics reduce value pluralism to "contradiction" and then condemn as incoherent any attempt of a legal regime to justify conclusions amid conflicting ideals, they fail to take seriously either the nature of value in modern society or the possibility that competing claims might be rationally reconciled.

As skeptical and liberal writers alike acknowledge, value conflict is a central feature of our moral and ethical lives: we feel the competing claims of a life of political engagement and personal attachment, intellectual rigor and sensuous fulfillment, global concern and local loyalty. ${ }^{106}$ Among these claims we choose and shape our lives, recognizing that they may not all be combined, that an increase in one dimension of value entails a diminution in others. ${ }^{107}$ Few today are willing to agree with Kant that moral duties can conflict only in appearance. ${ }^{108}$ Even in a very simple moral system, inconsistent

105. ISAIAH BERLIN, Alleged Relativism in Eighteenth-Century European Thought, in THE CROOKED TIMBER OF HUMANITY 70, 79-80 (Henry Hardy ed., 1991). This theme runs throughout Berlin's work. See, e.g., ISAIAH BERLIN, FOUR ESSAYS ON LIBERTY Xlix-1 (1969); cf. JOHN FINNIS, NATURAL LAW AND NATURAL RIGHTS 92-95 (1980) (arguing for an irreducibility of goods). The distinction drawn here between genetic and metaphysical explanations for conflicting values within legal regimes is not meant to deny that historical differences might be the explanation of metaphysical pluralism.

106. For CLS writers, see supra note 102. In addition to Berlin's work, see supra note 105 , the liberal case is made in: STUART HAMPSHIRE, MORALITY AND CONFLICT 140-69 (1983); THOMAS NAGEL, The Fragmentation of Value, in MORTAL QUESTIONS 128, 128-34 (1979) [hereinafter NAGEL, Fragmentation of Value]; THOMAS NAGEL, THE VIEW FROM NOWHERE 189-207 (1986); JOSEPH RAZ, THE MORALITY OF FREEDOM 395-99 (1986); and Susan Wolf, Moral Saints 79 J. PHIL. 419, 433-35, 437-39 (1982).

107. This point is especially well put by Wolf, supra note 106 , at 426 .

108. For Kant, a conflict between duties would be a contradiction in terms:

But since duty and obligation are concepts that express the objective practical necessity of certain actions and two rules opposed to each other cannot be necessary at the same time, if it 
obligations can arise both from merely contingent or factual conflict and from deeper conflicts in value. To take a standard example: someone may promise both to visit a relative and to take a friend to the airport; if the two promises are called in on the same day, then any account of morality must acknowledge the fact that the promisor has made two binding moral commitments and must break one to honor the other. ${ }^{109}$ Or consider the attorney whose professional obligations require breaking down the credibility of a child witness through hostile questioning. Even if one course of action seems right, the course not taken retains its moral claim, the loss of its associated values surfacing in the form of regret. ${ }^{110}$ The extreme case is what might be called tragic conflict, where one course of action is not merely incompatible with, but condemned by a competing set of values. ${ }^{11}$ Greek tragedy is the paradigm: Agamemnon must choose between honoring his commitments as the leader of his army and honoring his love and commitment to his daughter Iphigenia. ${ }^{112}$ Here it is not the case that more than one course of action is clearly right; each course of action is both absolutely abhorrent and absolutely required.

Our political thought recognizes the competing claims of value. The law mirrors these conflicts in its various expressions of the claims of welfare, justice, equality, fairness, and a range of liberties. Indeed, a central role for a system of laws in a pluralist society is mediating among differing conceptions of the good. ${ }^{113}$ In highly particular cases, liberty of religious expression competes with an interest in democratic education, ${ }^{114}$ liberty of political expression with egalitarian self-government, ${ }^{115}$ the protection of the economically vulnerable with free contract, ${ }^{116}$ product innovation with consumer protection. ${ }^{177}$ These specific conflicts are pedagogical chestnuts

is a duty to act in accordance with one rule, to act in accordance with the opposite rule is not a duty but even contrary to duty; so a collision of duties and obligations is inconceivable (obligationes non colliduntur).

KANT, supra note 93, at [224].

109. See BeRnard Williams, Ethical Consistency, in Problems of THE SelF 166, 175 (1973); Ruth B. Marcus, Moral Dilemmas and Consistency, 77 J. PHIL. 121 (1980).

110. See WILliaMS, supra note 109; BernaRd WILlIAMS, Moral Luck, in MORAL LuCK, supra note 54, at 20, 27-33; cf. GuIDo CALABRESI \& PHILIP BOBBITT, TRAGIC CHOICES 19-28 (1978) (discussing public choices where giving one individual a good means making others suffer).

111. For a similar distinction, though along slightly different lines, see WILliaMs, supra note 109, at 173; and BERNARD WILLIAMS, Conflicts of Values, in MORAL LuCK, supra note 54, at 71, 74.

112. Aeschylus, Agameminon, in SiX Greek Plays in MODERn Translation 1, 11 (Dudley Fitt ed. \& George Thomson trans., Dryden Press 1955) (n.d.).

113. See RAWLS, supra note 101 , at xix, 131-40.

114. See Wisconsin v. Yoder, 406 U.S. 205 (1972) (affirming First Amendment right of religious group to withdraw children from public education).

115. See Buckley v. Valeo, 424 U.S. 1 (1976) (holding limitations on campaign expenditures unconstitutional under First Amendment).

116. See Williams v. Walker-Thomas Fumiture Co., 350 F.2d 445 (D.C. Cir. 1965) (remanding case with suggestion that trial court find credit agreement unenforceable because unconscionable).

117. See Sills v. Massey-Ferguson, Inc., 296 F. Supp. 776 (N.D. Ind. 1969) (holding lawn mower manufacturer strictly liable for "design defect"). 
precisely because they are hard problems of law, requiring a choice among the various dimensions of value.

Whatever the frequency of genuinely tragic conflict in life and literature, or even in social policy, such conflicts are probably comparatively infrequent in the law. Judicial deliberations are typically a matter of weighing different considerations of value rather than attempts to resolve terrible dilemmas. In such cases of weak conflict, the conclusion of a line of reasoning along one dimension of value supports an action that contingently rules out an alternative; committing oneself to an academic life rules out devoting one's entire life to radical social change. Many of what CLS writers have called the "contradictions" of liberalism take this form, such as Kennedy's (now apparently recanted) "fundamental contradiction" between our simultaneous fear and longing for social membership. ${ }^{118}$ We do indeed favor both intimate attachment and a modicum of privacy, but tragic dilemma is usually averted through some combination of public participation and private pursuit of the good. Such middle- or low-grade conflicts permit a compromise because the competing values can be pursued in different domains. ${ }^{19}$

Even if tragic conflict is comparatively infrequent, weak conflict is sufficient to generate a troubling form of normative indeterminacy, at least as long as two incompatible decisions could be reached by emphasizing different sorts of value and there is no clearly preferable choice between the two. A pluralist society is characterized by irresolvable controversies about which values ought to command political authority. From this the skeptic concludes that any decisive resolution of conflict must be arbitrary or nonrational. Singer, for example, denies "that reason can adjudicate value conflicts" and advocates instead a model of existential commitment. ${ }^{120}$ Liberals like Dworkin respond that even persistent controversy is no reason to suppose that right choices among these divergent values are impossible. ${ }^{121}$ But Dworkin's response misses the point: if values are genuinely plural, then there neither can nor should be a successful technique for resolving all conflicts between them, such as the reduction of normative deliberation to a monistic calculus (e.g., wealth maximization), or the stipulation of an overarching principle to order values. Normative conflicts will simply reemerge when we seek to justify that framework for deliberation or that ordering of values.

118. Kennedy, Blackstone's Commentaries, supra note 102, at 211-12. The contradiction is recanted (or at least deemphasized) in Peter Gabel \& Duncan Kennedy, Roll Over Beethoven, 36 STAN. L. REV. 1, 15-18 (1984).

119. Altman argues that principled compromise is a necessity for liberalism. ALTMAN, supra note 5, at $71-72,145-47$.

120. Singer, supra note 3 , at 8 .

121. DWORKIN, supra note 14, at 331-38; Kress, Preface, supra note 4, at 139. 
The skeptical tendency to say that "nothing remains but to trust in our instincts," 122 that we must rely on a brute choice among competing values, is too easy: it avoids the difficult task of reasoning through cases of conflict to the utmost extent of their rational tractability. ${ }^{123}$ Ironically, the skeptic's model of normative reasoning is the most demanding imaginable: The skeptic demands that decisive reasons be available to defeat any contrary claim and then shows that legal reasoning can never live up to that model. But once that model has been eliminated, why should it not give way to a more pliable and realistic conception of normative reasoning, rather than to the abyss of unreason? We are not without rational resources even where disagreement is persistent: we can reason out the consequences of favoring one value over another, attempt to engage ourselves imaginatively in each claim put forward, practice various forms of compromise, and look to the concrete historical experiments in which different values have been pursued. ${ }^{124}$

True, the existence of irreconcilably conflicting considerations inevitably surrounds any decision with an air of contingency or luck. Another deliberator, finding different considerations salient, might have reached a different and incompatible conclusion. But this feature of luck at the heart of the legal system-the possibility of inconsistent conclusions-does not necessarily corrupt the conclusions actually generated, as is the case in some systems of formal reasoning. ${ }^{125}$ Much work in the philosophy of deontic logic, the logic of imperatives and obligations, has shown that coherent systems of reasoning can generate inconsistent conclusions without weakening inferential relationships. ${ }^{126}$ Despite the possibility of alternative courses of reasoning,

122. JeAn-PAUl SARTRE, ExisTENTIALISM AND HUMANISM 36 (Philip Mairet trans., Haskell House Publishers, Ltd. 1977) (1947); cf. Kennedy, Form and Substance, supra note 102, at 1775 ("The only kind of imagery that conveys the process by which we act and act and act in one direction, but then reach the sticking point, is that of existentialist philosophy. We make commitments, and pursue them.").

123. See Wiggins, supra note 83 , at 231 . As Bernard Williams puts it:

If 'rationality' entails the project of eliminating, ideally, all conflict, then rationality is a very qualified or partial virtue of a moral outlook or of the person who has it. If 'rationality' is taken to cover more generally the indisputable virtue of thinking intelligently and responsibly about one's desires and commitments, then the problematical issue is to what extent rationality demands consistency and the elimination of conflict, and in what forms.

BERNARD WILlIAMS, Consistency and Realism, in PROBLEMS OF THE SELF, supra note 109, at 187, 206. A corollary of this claim is the observation that intransitivity in preference orderings, individual or collective, is not a sign of irrationality, but a sign that goods are being compared along different dimensions of value that cannot be ordered lexically.

124. Michael Walzer discusses the relationship between distributive justice and the multiplicity of historically and socially constituted goods. See MICHAEL. WALZER, SPHERES OF JUSTICE 3-10 (1983).

125. Wittgenstein himself did not see contradictions as important threats to formal systems. "If you can draw any conclusion you like from it [the proposition ' $p$ and not- $p$ '], then that, as far as I can see, is all the trouble you can get into. And I would say, 'Well then, just don't draw any conclusions from a contradiction." LUDWIG WITTGENSTEIN, WITTGENSTEIN'S LECTURES ON THE FOUNDATIONS OF Mathematics 220 (Cora Diamond ed., 1976). However dubious the merits of this view may be in the case of formal systems, it is clearly right in the case of informal systems. See Charles S. Chihara, Wittgenstein's Analysis of the Paradoxes in his Lectures on the Foundations of Mathematics, 86 PHIL. REV. 365, 372 (1977).

126. See RESCHER, supra note 21 , at 74 (Logical theorists' investigations "have shown that one 
the decision actually made can still be defended by pointing to the reasons supporting it. The force of such reasons is not cancelled by the presence of competing considerations. If a choice is not outweighed by its alternatives, then that choice retains the justificatory force of its supporting rationale and preserves the argumentative connection to the public ideals from which it is derived.

If radical choice should not replace rational argument, neither should an appeal to an Aristotelian faculty of moral judgment, a source of determinate moral resolution where articulable grounds cannot be found. ${ }^{127}$ Although such a faculty is often invoked-and often criticized-in the domain of personal moral judgment, invoking it in the political realm amounts to a form of authoritarian intuitionism that is incompatible with the ideal of public justification. ${ }^{128}$ Here the skeptic's arguments are helpful in putting appeals to elite intuition in their proper place, for if there is an irreducible plurality of goods, any claim to have achieved final and determinate resolution of the conflict must be seen as spurious. Every decision can be reargued; different historical or individual emphases of the values involved will lead to divergent resolutions. Some decisions which had seemed obviously right in the past may now seem obviously mistaken. But so long as decisions are revisited with argument, bringing different values and reasons to bear, the ideal of the rule of law will not suffer. Although recognition of contingency at the heart of law will make us rethink our attitude towards the "immutable" decisions of the past, we need not fall into a general hatred or distrust of reason. ${ }^{129}$

Indeed, ineradicable conflict and divergence in a complex legal system is not a sign that things have gone awry, but that things are going well, that the legal regime is taking seriously plural claims of value. Vigorous dissents and weak doctrines of stare decisis, so long as they do not undermine the general stability of the legal regime, represent an important form of dialectical

emphatically need not adopt the stance that once $\mathrm{P}$ and not-P are both admitted, then 'anything goes' and any arbitrary $Q$ obtains. Inconsistency does not spread like a logical cancer into an all-pervasive logical chaos: it can represent a local and not necessarily global anomaly."). In this debate, the issue is whether a logic of obligation can do without the axiom "O(P) entails not-O(not-P)," i.e., whether the existence of an obligation to do something also entails not having an obligation not to do that thing. It has been shown that this is a largely metaphysical rather than logical issue, for accommodating logics can be constructed. For a seminal attempt to derive a logic without this axiom, see Bas C. van Fraassen, Values and the Heart's Command, 70 J. PHIL. 5 (1973). See also Peter K. Schotch \& Raymond E. Jennings, Non-Kripkean Deontic Logic, in NEW STUDIES IN DEONTIC LOGIC 149 (Risto Hilpinen ed., 1981).

127. See Charles E. Larmore, Patterns of Moral COMPlexity 5-14 (1987); Nagel, Fragmentation of Value, supra note 106, at 135. Larmore writes: "We might say that moral disagreement arises chiefly in areas where judgment must be exercised." LARMORE, supra, at 14.

128. See DwORKIN, Hard Cases, supra note 4, at 87 (arguing that intuitionism is incompatible with the rule of law). Intuitionist decisionmaking is apparently favored by Michael Oakeshott. See, e.g., Michael OAKeshotT, Political Education, in RATIONALISM IN POLITICS AND OThER ESSAYS 111, 119 (1962).

129. Nagel notes that recognition of the contingency of our justifications may lead us to regard them with "a certain irony and resignation." THOMAS NAGEL, The Absurd, in MORTAL QUESTIONS, supra note 106 , at $11,20$. 
engagement with the conflicting normative claims the regime incorporates. ${ }^{130}$ Thomas Paine could lend a motto to a healthy legal system: "I do not believe that any two men, on what are called doctrinal points, think alike who think at all. It is only those who have not thought that appear to agree."131

Contrary to the skeptic's argument, excessive convergence in a legal system is a sign of dysfunction, of a too-complacent acceptance of received principles and claims of value. Divergence, in contrast, signals that the techniques of reason and argumentative insight are playing a vigorous role in the law. The ideal of the rule of law is far better served by lively debate than by wooden consensus because debate renders the law's many values perspicuous in the actual exercise of authority. A useful analogy can be drawn with moral psychology: Just as a life that revealed no regret about difficult choices would reveal a lack of purpose and commitment, a legal system without frequent dissent and reversals of logic would be importantly blind to the genuine contours of political life.

Acceptance of the compatibility of reason and conflict is also the best basis for rooting systematic bias out of the law. Racism and other forms of pernicious bias survive only when legal forms are not questioned, when patterns of decision go unchallenged. When the demand for public justification is made with full force, and when controversial issues are revisited with fresh arguments and perspectives, systematic bias has nowhere to hide. Only when we ignore the skeptic's argument and accept claims of univocal solutions do we risk losing sight of the ideal of the rule of law.

\section{CONCLUSION}

Heraclitus wrote that justice is strife, ${ }^{132}$ we may now see the value of his remark. Examination of the skeptic's arguments has taught us to expect divergence, conflict, and inconsistency within vibrant legal institutions. But the truth in skepticism need not leave us in the whirlpool of doubt. Reason, argument, and justification are compatible with uncertainty and indeterminacy. Indeed, our willingness to tolerate reasoned dissent and divergence is a measure of our commitment to reason's place in the public sphere.

Reason is still secure for the rule of law, as long as the law is properly understood as a forum for argument and criticism and not for determinate conclusions. We may agree with Joseph Singer that outrage is necessary to the

130. See Robert Cover \& Alexander Aleinikoff, Dialectical Federalism: Habeas Corpus and the Court, 86 YALE L.J. 1035 (1977) (arguing that redundant federal and state habeas corpus proceedings create possibility of refined judgment).

131. Thomas Paine, The Rights of MAN 282-83 (Everyman's Library 1958) (1792). (n.d.).

132. HERACLITUS, FRAGMENTS 49 (Diels-Kranz Fragment 80) (T.M. Robinson ed. \& trans., 1987) 
struggle for social and individual justice, ${ }^{133}$ but we should never give up attempting to convince others that they, too, should be outraged. We should acknowledge the kernel of truth in the skeptical critique and exploit the wider array of arguments available in an underdetermined legal world, not shield our political and social order from rational scrutiny.

133. See Singer, supra note 3 , at 55 ("What protects us against Nazism is not the belief that reason can prove that it is wrong. What protects us is outrage."). 